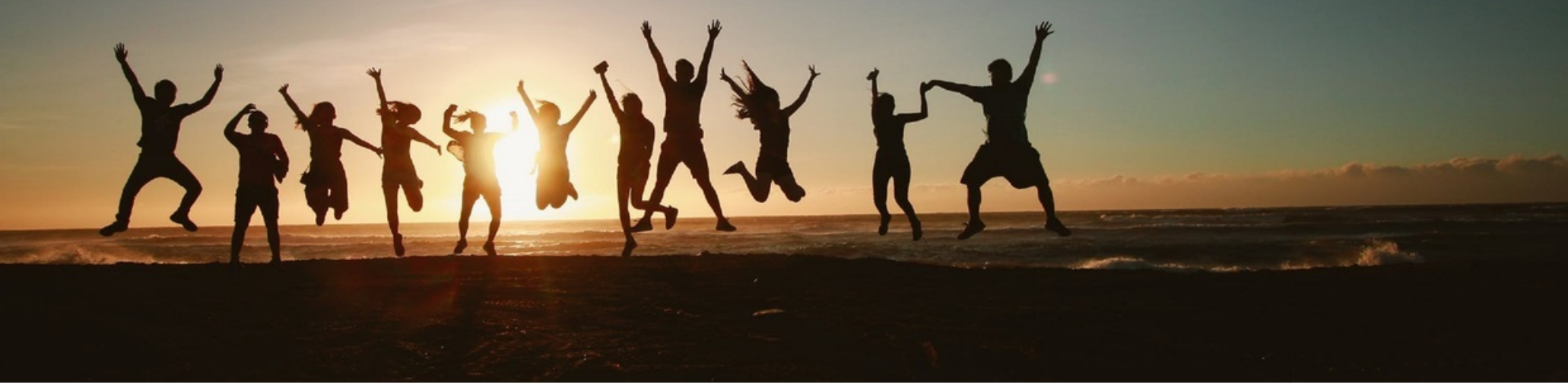

DEMETRIOS PRIZE 2019. The Winners!

Authors: Roland Mertelsmann, Gerhard Steinmann, Stephan Seiler

Submitted: 24. June 2019

Published: $\quad$ 27. June 2019

Volume: 6

Issue: 6

Affiliation: Uniklinik Freiburg, Med 1

Languages:

Keywords:

Categories:

English

Demetrios, competition, Humanities, Sciences, Arts, Prize 2019 Demetrios Project, News and Views

DOI: $\quad$ 10.17160/josha.6.6.574

\title{
Abstract:
}

The JOSHA Team is very pleased to share with you information about our second Demetrios Prize 2019. For the categories BACHELOR, MASTER and DOCTORAL thesis the International Academy of Science, Humanities and Arts (IASHA e.V.) supported by the Biothera Foundation had selected 3 theses in each category and award a prize of $€ 500$ each. Our editors have selected the winners and their manuscripts will be published in the Journal of Science, Humanities, and Arts - JOSHA, with a unique DOI for each paper. CONGRATULATIONS!! 


\section{DEMETRIOS - PRIZE 2019}

The JOSHA Team is very pleased to share with you the names of the Winners of the Demetrios Prize 2019.

For the categories BACHELOR and MASTER thesis the International Academy of Science, Humanities and Arts (IASHA e.V.) supported by the Biothera Foundation has selected 9 theses in different categories and award a prize of $€ 500$ each. Our editors have chosen 3 Bachelor Thesis, 3 Master Thesis, and 2 Doctoral Thesis in the Fields of medicine, philosophy, literature, and arts. The winners of the Demetrios Prize 2019 are:

\section{Bachelor of Arts}

*Maria Sandoval with "La migración como tema en el cine latinoamericano: frontera entre México y Los Estados Unidos." in Literature.

*Julia Pinter with "Optimizing T-Cell Culture in Microfluidic Devices" in Medicine.

*Yasemin Soydan with "Die Darstellung des intergenerationellen Traumas im Film La teta asustada von Claudia Llosa" in Literature.

\section{Master Thesis/Lic./Staatsexam}

*Joaquín Campodónico with "El pathos trágico en el joven Nietzsche". Philosophy.

*Federico Abal with „Tortura: permisibilidad, mundo real y legislación“. Philosophy.

*Guido Selim Arditi with "El amor romántico desde una mirada marxista". Philosophy.

\section{Doctor Thesis}

*Nikolas Woitzik with "Machine Learning as an Adjunct to Medical Decision Making". Medicine.

*Diego Guzman A. with "Functional outcomes of radial head fractures type III and IV, after management with arthroplasty or internal fixation." Medicine.

The manuscripts will be published in the Journal of Science, Humanities, and Arts - JOSHA, with a unique DOI for each paper and the winners will receive their prize money and their diplomas in a festive act on July 6 .

The "Journal of Science, Humanities and Arts - JOSHA" has been initiated to create a novel internet platform to access the broad diversity of important discoveries and creativity in the fields of Science, Humanities and Arts. 